\title{
Removal of polychlorinated biphenyls by desulfurization and emissions of polychlorinated biphenyls from sintering plants
}

\author{
Mengjing Wang ${ }^{1,2} \cdot$ Meifang Hou ${ }^{1} \cdot \mathrm{Kai} \mathrm{Zhao}^{2} \cdot$ Haifeng $\mathrm{Li}^{2} \cdot \mathrm{Ying} \mathrm{Han}^{2} \cdot \mathrm{Xiao} \mathrm{Liao}^{2}$ • \\ Xuebin Chen ${ }^{2} \cdot$ Wenbin Liu ${ }^{2}$
}

Received: 27 September 2015 / Accepted: 30 November 2015 /Published online: 22 December 2015

(C) Springer-Verlag Berlin Heidelberg 2015

\begin{abstract}
The influence of desulfurization on polychlorinated biphenyls (PCBs) from sintering plants was investigated. The concentrations of dioxin-like (dl) PCBs, toxic equivalents (TEQs), indicator PCBs, and total tri- to deca-chlorinated PCB homolog groups ( $\sum$ PCBs) in the flue gases at the desulfurization system inlets were $290-1906 \mathrm{pg} \mathrm{m}^{-3}(2.4-18.8 \mathrm{pg}$ World Health Organization (WHO) TEQ $\mathrm{m}^{-3}$ ), 420$2885 \mathrm{pg} \mathrm{m}^{-3}$, and $6496-22,648 \mathrm{pg} \mathrm{m}^{-3}$, respectively. Desulfurization reduced the values to $43.3-500 \mathrm{pg} \mathrm{m}^{-3}$ (0.46-9.5 pg WHO-TEQ $\left.\mathrm{m}^{-3}\right), 183-587 \mathrm{pg} \mathrm{m}^{-3}$, and 2383$11,639 \mathrm{pg} \mathrm{m}^{-3}$, respectively. The removed PCBs were adsorbed by gypsum from the flue gas; the PCB concentration distributions at the inlets and outlets and in the gypsum samples were similar. The emission factors were $9.86 \mathrm{ng}$ WHOTEQ $\mathrm{t}^{-1}$ for the flue gas and $8.37 \mathrm{ng}$ WHO-TEQ $\mathrm{t}^{-1}$ for gypsum. Desulfurization decreased the annual atmospheric PCB emissions from 48.6 to $30.7 \mathrm{~g} \mathrm{WHO-TEQ}$, and the estimated annual emissions in gypsum were $8.06 \mathrm{~g}$ WHO-TEQ. PCBs in the gypsum have not been effectively eliminated and will probably reenter the environment and in turn become a new source of PCB emission. The PCB concentrations in fly ashes
\end{abstract}

Responsible editor: Hongwen Sun

Meifang Hou

mfhou@sit.edu.cn

Wenbin Liu

liuwb@rcees.ac.cn

School of Ecological Technology and Engineering, Shanghai Institute of Technology, Shanghai 201418, China

2 State Key Laboratory of Environmental Chemistry and Ecotoxicology, Research Center for Eco-Environmental Sciences, Chinese Academy of Sciences, P.O. Box 2871, Beijing 100085, China from series-connected electrostatic precipitators clearly increased.

Keywords Polychlorinated biphenyls · Desulfurization · Removal · Gypsum $\cdot$ Fly ash $\cdot$ Emission factor

\section{Introduction}

Polychlorinated biphenyls (PCBs) are covered by the Stockholm Convention on Persistent Organic Pollutants (POPs), because they are toxic, stable, persistent in the environment, and semi-volatile. These properties make it possible for PCBs to undergo long-range transport, and they pose global risks to human health and the environment (Liu et al. 2009a; Meijer et al. 2003; Ren et al. 2007). The manufacture and use of commercial products containing PCBs were banned in most countries in 1973. Consequently, unintentional emissions of PCBs during industrial thermal processes have been becoming, and will continue to become, more important sources of PCBs in the environment. These thermal emission sources of PCBs include iron sintering, secondary nonferrousmetal smelting, iron casting, coking, and converter steelmaking; iron-ore sintering is an important industrial source of PCBs (Ba et al. 2010; Ba et al. 2009; Li et al. 2014; Liu et al. 2009a; Liu et al. 2009b; Luthardt et al. 2002; Lv et al. 2011; Tian et al. 2012). The environmental presence and behaviors of PCBs have been studied for more than 30 years ( $\mathrm{Li}$ et al. 2010). but the sources and ways of controlling and eliminating PCBs still need to be studied to enable measures to decrease the release of PCBs from some industries (Jansson and Andersson 2012).

In China, sintering processes are an important source of $\mathrm{SO}_{2}$, accounting for $7 \%$ of total industrial emissions. Desulfurization systems are used as end-of-pipe solutions for 
removing $\mathrm{SO}_{2}$ from flue gases produced in sintering plants. Sintering plants are required to install desulfurization systems to satisfy local legislation on permissible emissions limits. However, systematic research on simultaneous removal of PCBs from sintering flue gas using desulfurization systems has rarely been reported.

In this study, four typical sintering plants were investigated to evaluate the emissions and profiles of PCBs in sintering processes and the influence of desulfurization systems on PCB emissions. The aim was to improve our understanding of PCB emissions in the sintering industry to enable reduction of PCB emissions to protect the environment and human health.

\section{Materials and methods}

\section{Sampling}

The main desulfurization processes that are currently used are wet and semi-dry processes. Sintering plants larger than $180 \mathrm{~m}^{2}$ are usually modern plants equipped with advanced semi-dry desulfurization systems, whereas sintering plants smaller than $180 \mathrm{~m}^{2}$ are usually old and need to be updated, and often have wet desulfurization systems. Four typical sintering plants (labeled DH, TS, SK, and ST) with different sintering capacities and using different desulfurization processes were selected; information on the selected plants is presented in Table 1.

A series of flue gas, fly ash, and gypsum samples were collected from the sintering plants. Six flue gas samples were collected from each sintering plant; three samples were collected at the desulfurization system inlet and three were collected at the desulfurization system outlet. The flue gas samples were collected using an automatic isokinetic sampling system (TCR TECORA, Italy). The sampling method has been described in detail previously (Ba et al. 2010). Briefly, the sampling train consisted of a heated probe, a filter box with a quartz-fiber filter, and a water-cooled XAD-2 adsorbent trap. The quartz-fiber filter was used to collect particlebound pollutants, and the XAD-2 adsorbent resin was used to trap vapor-phase contaminants. Four fly ash samples were individually collected at different stages of the seriesconnected electrostatic precipitators of the DH and TS plants, and one mixed fly ash sample was collected from the electrostatic precipitators of the SK and ST plants. In addition, a gypsum sample was collected from the desulfurization system of each plant.

\section{Sample preparation and PCB analysis}

In this study, PCB analysis was conducted using a modified version of an Environmental Protection Agency method EPA-1668; the sample extraction and cleanup procedures and instrumental details have been described previously (Nie et al. 2012). Briefly, the samples were spiked with known amounts of a mixture of ${ }^{13} \mathrm{C}_{12}$-labeled PCB internal standards (1668A-LCS; Cambridge Isotope Laboratories, Andover, MA, USA) and then extracted with toluene $(250 \mathrm{~mL})$, using a Soxhlet system, for about $24 \mathrm{~h}$. Before Soxhlet extraction, the fly ash and gypsum samples were treated with $\mathrm{HCl}(1 \mathrm{M})$. The extracts were purified using multilayer silica-gel columns and basic alumina columns. The extracts were evaporated to about $20 \mu \mathrm{L}$, and a mixture of ${ }^{13} \mathrm{C}_{12}$-labeled PCB injection standards (1668A-IS; Cambridge Isotope Laboratories) was added. The PCB concentrations were determined using an Agilent 6890 gas chromatograph (Agilent Technologies, Santa Clara, CA, USA) with a DB-5 ms fused-silica column $(60 \mathrm{~m} \times 0.25 \mathrm{~mm} \times 0.25 \mu \mathrm{m}$; Agilent Technologies), coupled with a Waters Autospec Ultima high-resolution mass spectrometer (Waters, Milford, MA, USA). The ${ }^{13} \mathrm{C}_{12}$-labeled PCB standard recoveries were 43.7-137.6\%. Laboratory method blanks were run with each batch of samples.
Table 1 Operating information for sintering plants

\begin{tabular}{|c|c|c|c|c|c|}
\hline \multicolumn{2}{|l|}{ Item } & DH & TS & SK & ST \\
\hline \multicolumn{2}{|l|}{ Sintering size $\left(\mathrm{m}^{2}\right)$} & 90 & 180 & 360 & 500 \\
\hline \multicolumn{2}{|c|}{ Annual output of sintering $\left(\times 10^{4} \mathrm{t}\right)$} & 80 & 220 & 400 & 695 \\
\hline \multirow[t]{4}{*}{ Feed materials $(\%)$} & Iron ore & 63.4 & 64 & 71 & 66.7 \\
\hline & Limestone & 11.5 & 9 & 5 & 9.4 \\
\hline & Coke & 5.4 & 9 & 4 & 4.9 \\
\hline & Recycled dust & 20.1 & 18 & 20 & 19 \\
\hline \multicolumn{2}{|c|}{ Desulfurization process } & Wet & Semi-dry & Semi-dry & Semi-dry \\
\hline \multicolumn{2}{|c|}{ Average temperature of flue gas $\left({ }^{\circ} \mathrm{C}\right)$} & 57.4 & 133 & 149.2 & 182.7 \\
\hline \multicolumn{2}{|c|}{ Average flue gas flow $\left(\mathrm{m}^{3} \mathrm{~h}^{-1}\right)$} & 720,000 & $1,620,000$ & $1,810,000$ & 170,000 \\
\hline \multicolumn{2}{|c|}{ Output of gypsum (t year $\left.{ }^{-1}\right)$} & 6000 & 18,000 & 40,000 & 53,000 \\
\hline \multicolumn{2}{|c|}{ Output of fly ash $\left(t\right.$ year $\left.^{-1}\right)$} & 2344 & 5115 & 7088 & 16,772 \\
\hline
\end{tabular}


Brunauer-Emmett-Teller was characterized using an ASAP 2020 specific surface area and porosity analyzer (Micromeritics Instrument Corp., Norcross, GA, USA); total organic carbon content was analyzed by a TOC Analyzer (OI Analytical, College Station, Texas, USA), and particle sizes were examined by using SALD-2300 laser diffraction particle size analyzer (Shimadzu Corporation, Kyoto, Japan).

\section{Results and discussion}

\section{Concentrations of PCBs in flue gas and gypsum samples}

Dioxin-like (dl) PCBs (PCB-77, PCB-81, PCB-105, PCB114, PCB-118, PCB-123, PCB-126, PCB-156, PCB-157, PCB-167, PCB-169, and PCB-189), indicator PCBs (PCB28, PCB-52, PCB-101, PCB-138, PCB-153, PCB-180, and PCB-209), and total tri- to deca-chlorinated PCB homologs ( $\sum \mathrm{PCBs}$ ) were investigated; their concentrations in the samples are listed in Table 2. The dl-PCB toxic equivalents (TEQs) were calculated using the World Health Organization (WHO) TEQ factors (Van et al. 2006).

The dl-PCB concentrations in the flue gases at the desulfurization systems inlets were $290-1906 \mathrm{pg} \mathrm{m}^{-3}$ (2.4$18.8 \mathrm{pg}$ WHO-TEQ $\mathrm{m}^{-3}$ ) and decreased to $43.3-500 \mathrm{pg} \mathrm{m}^{-3}$
(0.46-9.5 pg WHO-TEQ $\mathrm{m}^{-3}$ ) at the outlets. Aries et al. (2006) found PCB concentrations of 42-111 pg WHOTEQ $\mathrm{m}^{-3}$ in flue gases emitted from sintering plants in the $\mathrm{UK}$; these are much higher than the concentrations found in this study. The dl-PCB concentrations in the gypsum samples were in the range $29.0-170 \mathrm{pg} \mathrm{g}^{-1}(0.61-2.37 \mathrm{pg}$ WHOTEQ $\mathrm{g}^{-1}$ ). It is worth noting that considerable amounts of PCBs were found in the gypsum samples; the PCBs are transferred from the flue gas to the gypsum particles in the desulfurization systems.

The concentrations of indicator PCBs in the flue gases at the desulfurization systems inlets were $420-2885 \mathrm{pg} \mathrm{m}^{-3}$, and these decreased to $183-587 \mathrm{pg} \mathrm{m}^{-3}$ at the outlets. The $\sum$ PCB concentrations at the inlets were $6496-22,648 \mathrm{pg} \mathrm{m}^{-3}$ and decreased to 2383-11,639 $\mathrm{pg} \mathrm{m}^{-3}$. Liu et al. (2013a) reported indicator PCBs and $\sum$ PCB levels from sintering plants were 295-14,000 $\mathrm{pg} \mathrm{m}^{-3}$ and $1560-58,900 \mathrm{pg} \mathrm{m}^{-3}$. The concentrations of indicator PCBs and $\sum \mathrm{PCB}$ for sintering plants investigated in this study were lower than those reported by Liu et al. (2013a).

Routine measurement of PCBs is currently complicated and expensive. It is necessary to be performed to identify possible marker congeners for and TEQ values during sintering process. The correlations between PCBs congeners and TEQ values were examined in this study. Good linear correlations were found between the concentrations of the
Table 2 PCB concentrations $\left(\mathrm{pg} \mathrm{m}^{-3} ; \mathrm{pg} \mathrm{g}^{-1}\right)$ and TEQs

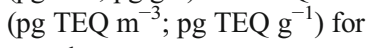
samples

\begin{tabular}{|c|c|c|c|c|c|c|}
\hline & & & dl-PCBs & dl-PCBs TEQ & Indicator PCBs & $\sum$ PCBs \\
\hline \multirow{8}{*}{ Flue gas } & Inlet & $\mathrm{DH}$ & $716 \pm 203$ & $11.9 \pm 2.7$ & $2240 \pm 528$ & $8021 \pm 1525$ \\
\hline & & $\mathrm{TS}$ & $1408 \pm 498$ & $13.4 \pm 5.4$ & $2509 \pm 376$ & $8867 \pm 1549$ \\
\hline & & SK & $580 \pm 290$ & $6.3 \pm 3.9$ & $1259 \pm 839$ & $16,925 \pm 2608$ \\
\hline & & ST & $1030 \pm 560$ & $7.2 \pm 2.6$ & $1445 \pm 908$ & $18,081 \pm 4567$ \\
\hline & Outlet & DH & $284 \pm 43.2$ & $2.8 \pm 0.90$ & $528 \pm 59.2$ & $6118 \pm 2329$ \\
\hline & & $\mathrm{TS}$ & $194 \pm 27.3$ & $0.68 \pm 0.06$ & $266 \pm 43.7$ & $4451 \pm 2068$ \\
\hline & & SK & $92 \pm 48.7$ & $0.60 \pm 0.14$ & $301 \pm 33.0$ & $6934 \pm 1320$ \\
\hline & & $\mathrm{ST}$ & $466 \pm 34$ & $6.7 \pm 2.8$ & $371 \pm 188$ & $9247 \pm 2392$ \\
\hline \multirow[t]{4}{*}{ Gypsum } & $\mathrm{DH}$ & & 120 & 2.36 & 283 & 1196 \\
\hline & $\mathrm{TS}$ & & 29.0 & 0.61 & 204 & 866 \\
\hline & SK & & 170 & 2.37 & 1828 & 5863 \\
\hline & ST & & 151 & 2.21 & 1379 & 3961 \\
\hline \multirow[t]{10}{*}{ Fly ash } & $\mathrm{DH}$ & Stage 1 & 510 & 10.1 & 1476 & 3962 \\
\hline & & Stage 2 & 630 & 10.8 & 1539 & 8441 \\
\hline & & Stage 3 & 715 & 13 & 1969 & 10,741 \\
\hline & & Stage 4 & 943 & 19.5 & 2255 & 20,316 \\
\hline & $\mathrm{TS}$ & Stage 1 & 490 & 8.1 & 1476 & 7933 \\
\hline & & Stage 2 & 577 & 8.2 & 2460 & 16,285 \\
\hline & & Stage 3 & 1123 & 17.4 & 3551 & 21,626 \\
\hline & & Stage 4 & 1471 & 27.1 & 5080 & 22,670 \\
\hline & \multicolumn{2}{|c|}{ SK (mixed) } & 1004 & 18.9 & 725 & 4564 \\
\hline & \multicolumn{2}{|c|}{ ST (mixed) } & 646 & 10.7 & 709 & 7530 \\
\hline
\end{tabular}


congeners PCB-126, PCB-156, PCB-157, PCB-167, and the TEQ values $\left(R^{2}>0.90, p<0.01\right)$. Congener PCB-126 was relatively abundant in flue gas samples; therefore, the PCB-126 level was easy to determine. Congener PCB-126 can therefore be used to predict TEQ values from indicator concentrations using linear equations in the flue gas at the inlet and outlet.

\section{Concentrations of PCBs in fly ash samples from sintering plant}

The data in Table 2 show that the dl-PCB concentrations in fly ash samples were 490-1471 $\mathrm{pg} \mathrm{g}^{-1}$ (8.1-27.1 pg WHOTEQ $\mathrm{g}^{-1}$ ). The concentrations of PCBs in fly ash from sintering processes have seldom reported, and no other published data on PCB levels from sintering processes are available for comparison. However, the PCBs from some other thermal industries have been reported, including converter steelmaking processes $\left(0.036-0.75 \mathrm{ng} \mathrm{g}^{-1}\right.$ for dl-PCB, 0.03$2.85 \mathrm{pg}$ WHO-TEQ $\left.\mathrm{g}^{-1}\right)$, iron foundries $(0.028-$ $9.34 \mathrm{pg}$ WHO-TEQ $\mathrm{g}^{-1}$ ), secondary aluminum production (0.018-10.2 ng TEQ $\mathrm{g}^{-1}$ ), and secondary copper production (0.003-103.1 ng TEQ g ${ }^{-1}$ ) (Li et al. 2014) (Ba et al. 2010; Lv et al. 2011). The levels of PCBs in fly ash samples from sintering processes were far higher than those of converter steelmaking processes, iron foundries, secondary copper production, and secondary copper production. The indicator PCB and $\sum \mathrm{PCB}$ concentrations in fly ash in this study were in the ranges 709-5080 and 4564-22,670 $\mathrm{pg} \mathrm{g}^{-1}$, respectively.

The PCB concentrations in fly ash samples from seriesconnected electrostatic precipitators from the DH and TS sintering plants clearly showed an increasing trend. The average increases were $35.4 \%$ for dl-PCBs, $41.1 \%$ for TEQs, $33.5 \%$ for indicator PCBs, and $44.3 \%$ for $\sum$ PCBs. The characteristics of the fly ash samples from the DH and TS plants are shown in Fig. 1.

We can clearly see that the particle size decreased and the Brunauer-Emmett-Teller surface area and total organic carbon content both increased moving from the first to the fourth stage of the series-connected electrostatic precipitator in each plant. This shows that the finer fly ash has a higher specific surface area, which favors the adsorption of PCB. The higher amount of organic carbon in the fly ash was related to higher levels of PCBs in the fly ash.

\section{PCB concentration profiles in flue gas and gypsum samples}

The PCB profiles in flue gas and gypsum samples are shown in Fig. 2. The PCB concentrations in the gypsum samples are normalized to an emission of $1 \mathrm{~m}^{3}$ of flue gas, to minimize the influence of total concentration and enable comparison of the sample compositions.

The dl-PCB, indicator $\mathrm{PCB}$, and $\mathrm{PCB}$ distributions in flue gas samples at the desulfurization system inlets and outlets and gypsum samples were similar. Which is attributed to the PCBs were removed from the flue gas by the desulfurization system and transferred to the gypsum.

The dl-PCB congener profiles in flue gas and gypsum samples are shown in Fig. 2a. The dl-PCB profiles of the flue gas samples were similar to those found in previous studies (Aries et al. 2006). The three dominant congeners in the flue gases at the desulfurization system inlets were PCB-77, PCB-105, and PCB-118, with average concentrations of $259.3,95.3$, and $94.2 \mathrm{pg} \mathrm{m}^{-3}$. The three dominant congeners in the flue gases at the outlets were PCB-77, PCB-118, and PCB-123; their average concentrations decreased to $62.97,31.45$, and $26.14 \mathrm{pg} \mathrm{m}^{-3}$. The three dominant congeners in gypsum samples were PCB-77, PCB-118, and PCB-105; the corresponding average concentrations were $161.1,62.8$, and $60.0 \mathrm{pg} \mathrm{m}^{-3}$. The TEQ congener profiles are shown in Fig. 2b. The most abundant TEQ congener in the flue gases at the inlets was PCB-126 (mean 8.9 pg WHO-TEQ $\mathrm{m}^{-3}$ ), the most abundant TEQ congener in gypsum was PCB-126 (mean 5.7 pg WHOTEQ $\mathrm{m}^{-3}$ ), and PCB-126 congener concentrations in the flue

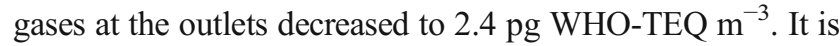
worth noting that most of the TEQs in the sintering flue gas were removed and transferred to the gypsum samples.

The PCB-118 to PCB-77 concentration ratios $\left(R_{\mathrm{CB}-118 / \mathrm{CB}-}\right.$ 77) vary considerably from different thermal-related processes (Liu et al. 2013). For example, in secondary-metal smelting, the $R_{\mathrm{CB}-118 / \mathrm{CB}-77}$ ranges from about 3.7 to 5.4 , and for electric arc furnaces for steel and cement production, $R_{\mathrm{CB}-118 / \mathrm{CB}-77}$ is
Fig. 1 Characteristics of fly ash samples (Size particle size, BET Brunauer-Emmett-Teller surface area, TOC total organic carbon)

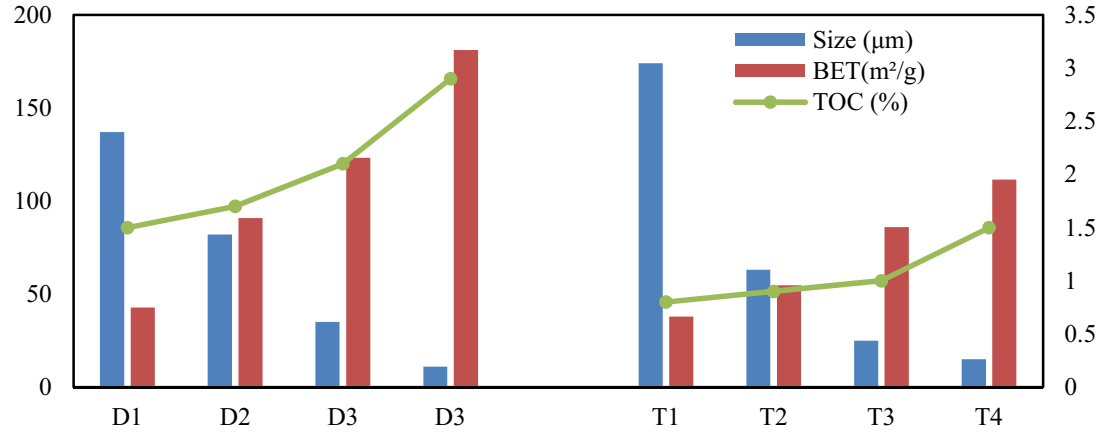


Fig. 2 Concentration profiles of Dl-PCBs (a), TEQ (b), indicator PCBs (c), and $\sum$ PCBs (d) in flue gas and gypsum samples
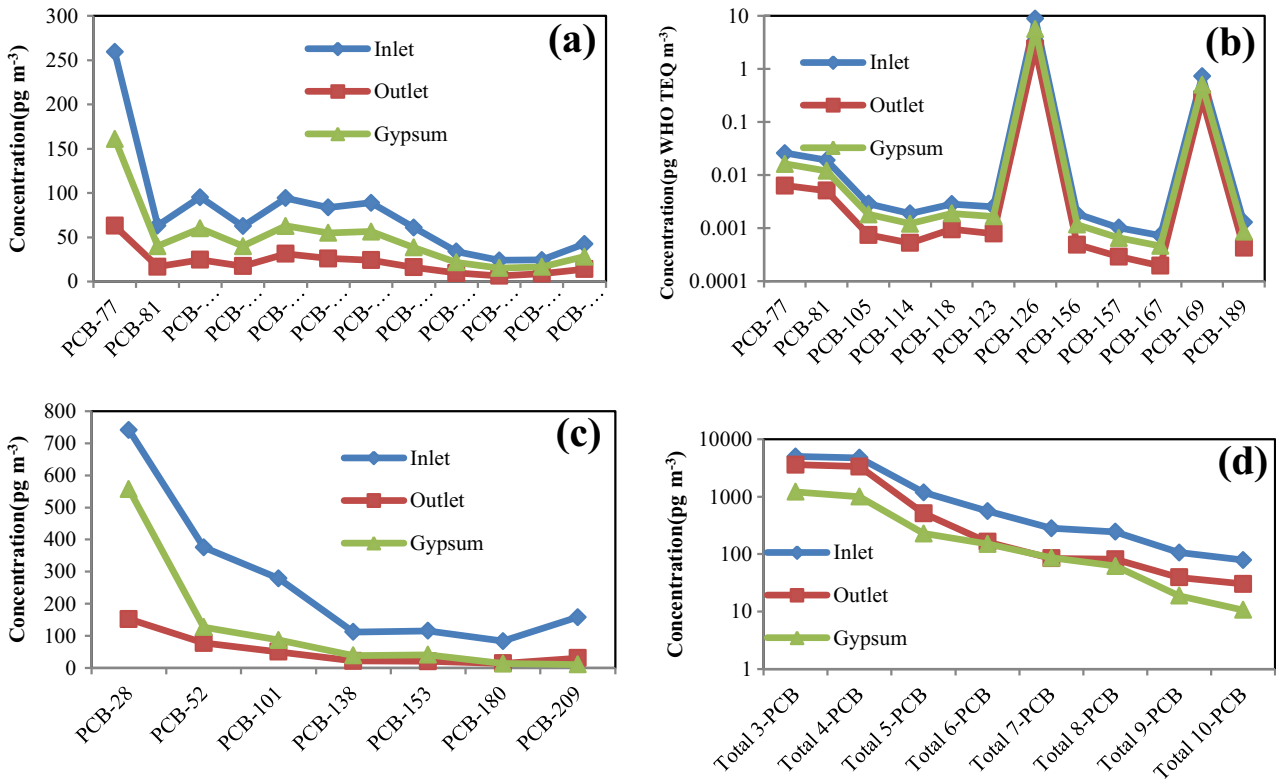

about 2.0-2.6. The $R_{\mathrm{CB}-118 / \mathrm{CB}-7}$ values for flue gases at the inlet and outlet in this study were 0.36 and 0.49 , those for the gypsum samples were about 0.87 , and those for the fly ash samples were about 0.40 . The $R_{\mathrm{CB}-118 / \mathrm{CB}-77}$ concentration ratios can be used to study source-receptor relationships and to identify specific sources of PCB emissions to the environment.

The indicator PCB congener profiles in flue gas and gypsum samples are shown in Fig. 2c. The overall congener profiles in flue gas samples were similar to those observed in previous studies (Liu et al. 2013). The indicator PCB congener concentration generally decreased with increasing chlorination level. The dominant congener in the flue gases at the desulfurization system inlets and outlets and in the gypsum samples was PCB-28, and the corresponding average concentrations were 741,152 , and $557 \mathrm{pg} \mathrm{m}^{-3}$.
The PCB homolog profiles in the flue gas and gypsum samples are shown in Fig. 2d. The PCB homolog concentration decreased with increasing chlorination level of the homo$\log$. The dominant PCB homolog in the flue gases at the desulfurization system inlets and outlets and gypsum samples was a trichlorinated biphenyl homolog; the corresponding average concentrations were 5539, 3306, and $1213 \mathrm{pg} \mathrm{m}^{-3}$.

The removal efficiencies for the PCB homologs by the desulfurization systems are shown in Fig. 3. The PCB homolog removal efficiency by the desulfurization systems increased with increasing chlorination levels of the congeners. Generally, lower chlorinated PCBs with higher vapor pressures are more likely to distribute to gaseous phase, while higher chlorinated PCBs are more likely to distribute to solid phase (Karademir et al. 2004). Solid particles in sintering flue gas were intercepted by desulfurization systems, since the
Fig. 3 Removal efficiencies for PCB homologs

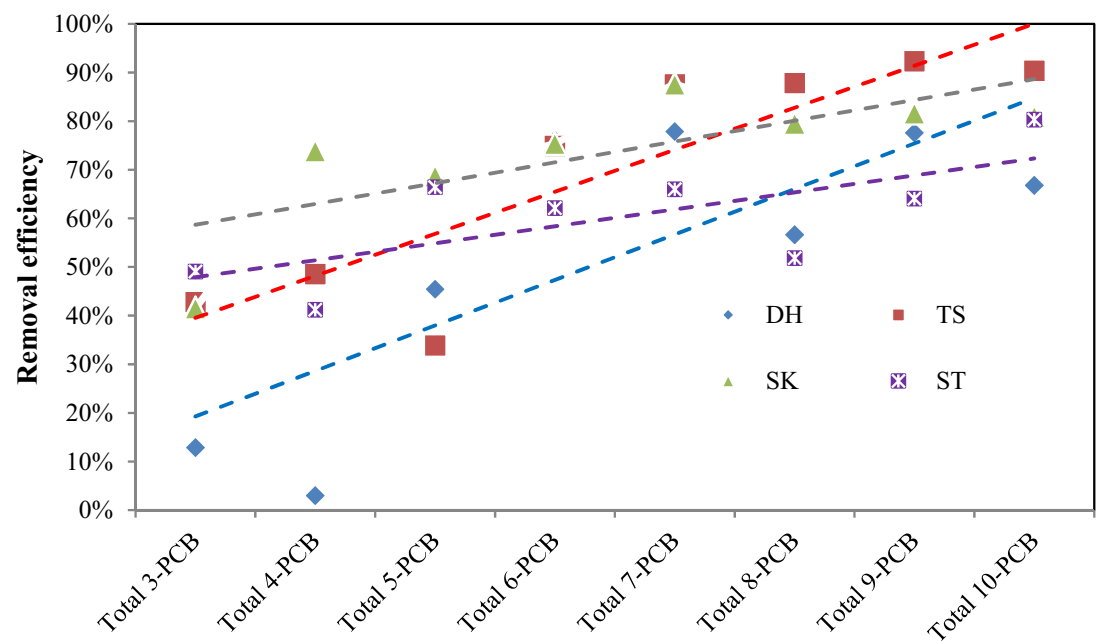


systems can effectively remove solid-phase PCBs and it is ineffective in removing particle-phase PCBs. The highchlorinated $\mathrm{PCB}$ congeners have higher removal efficiency than low-chlorinated ones.

\section{PCB emission factors and estimated total amounts of PCBs emitted to the atmosphere and in gypsum}

The emission factors and amounts of PCBs emitted were calculated using previously reported equations (Liu et al. 2014).

The means of the TEQ emission factors were $50.4 \mathrm{ng}$ WHO-TEQ $\mathrm{t}^{-1}$ for the flue gases at the desulfurization system inlets, and $9.86 \mathrm{ng}$ WHO-TEQ $\mathrm{t}^{-1}$ for the flue gases at the outlets. The PCB emission factors at the outlets were comparable to that (12.4 ng WHO-TEQ $\mathrm{t}^{-1}$ ) reported by Liu et al. (Liu et al. 2013b). The TEQ emission factors were $8.37 \mathrm{ng}$ WHO-TEQ $\mathrm{t}^{-1}$ for gypsum. The fly ash produced in the sintering plants was recycled to recover residual metals; therefore, PCBs emitted from fly ash can be neglected.

Taking the output of China sintering ore in 2012, the sintering output reached about 964 million tons and the desulfurization ratios of sintering plants were about $48.6 \%$. Preliminary estimates of annual dl-PCB WHO-TEQ emissions by the Chinese sintering industry were $30.7 \mathrm{~g}$ WHOTEQ to air and $8.06 \mathrm{~g}$ WHO-TEQ in gypsum. The efficiency of emission removal by desulfurization systems is $36.8 \%$, compared with emissions in the absence of desulfurization systems, and the annual dl-PCB WHO-TEQ emissions to air would be $48.6 \mathrm{~g}$ WHO-TEQ. However, the emission of dlPCB TEQ released to air and gypsum were much higher than those of electric arc furnace for steel making (4.1 g TEQ) (Liu et al. 2013). municipal solid waste incineration ( $0.77 \mathrm{~g}$ TEQ) (Liu et al. 2013). and medical waste incineration (2.4 g TEQ) (Liu et al. 2013).

\section{Conclusions}

We investigated the influence of desulfurization systems on PCB emission concentrations, profiles, and emission factors from the sintering industry. Considerable amounts of PCBs were effectively removed by desulfurization installations and transferred to gypsum; however, PCBs in the gypsum have not been effectively eliminated and will probably reenter the environment and in turn become a new source of PCB emission. In addition, although PCBs were controlled by desulfurization systems, sintering processes are still an important source of unintentional PCBs in China, and annual emissions were $30.7 \mathrm{~g}$ WHO-TEQ.

Acknowledgments This study was supported by the National 973 Program (2015CB453103), the Strategic Priority Research Program of the
Chinese Academy of Sciences (XDB14020102), and the National Natural Science Foundation of China (21477150 and 21321004).

\section{References}

Aries E, Anderson DR, Fisher R, Fray TA, Hemfrey D (2006) PCDD/F and "Dioxin-like" PCB emissions from iron ore sintering plants in the UK. Chemosphere 65:1470-1480

Ba T, Zheng M, Zhang B, Liu W, Xiao K, Zhang L (2009) Estimation and characterization of $\mathrm{PCDD} / \mathrm{Fs}$ and dioxin-like $\mathrm{PCBs}$ from secondary copper and aluminum metallurgies in China. Chemosphere 75: $1173-1178$

Ba T, Zheng M, Zhang B, Liu W, Su G, Liu G, Xiao K (2010) Estimation and congener-specific characterization of polychlorinated naphthalene emissions from secondary nonferrous metallurgical facilities in China. Environ Sci Technol 44:2441-2446

Jansson S, Andersson PL (2012) Relationships between congener distribution patterns of PCDDs, PCDFs, PCNs, PCBs, PCBzs and PCPhs formed during flue gas cooling. Sci Total Environ 416:269-275

Karademir A, Bakoglu M, Taspinar F, Ayberk S (2004) Removal of $\mathrm{PCDD} /$ Fs from flue gas by a fixed-bed activated carbon filter in a hazardous waste incinerator. Environ Sci Technol 38:1201-1207

Li S, Zheng M, Liu W, Liu G, Xiao K, Li C (2014) Estimation and characterization of unintentionally produced persistent organic pollutant emission from converter steelmaking processes. Environ Sci Pollut Res Int 21:7361-7368

Li Y, Wang P, Ding L, Li X, Wang T, Zhang Q, Yang H, Jiang G, Wei F (2010) Atmospheric distribution of polychlorinated dibenzo-p-dioxins, dibenzofurans and dioxin-like polychlorinated biphenyls around a steel plant area, Northeast China. Chemosphere 79:253258

Liu G, Zheng M, Ba T, Liu W, Guo L (2009a) A preliminary investigation on emission of polychlorinated dibenzo-p-dioxins/dibenzofurans and dioxin-like polychlorinated biphenyls from coke plants in China. Chemosphere 75:692-695

Liu G, Zheng M, Liu W, Wang C, Zhang B, Gao L, Su G, Xiao K, Lv P (2009b) Atmospheric emission of PCDD/Fs, PCBs, hexachlorobenzene, and pentachlorobenzene from the coking industry. Environ Sci Technol 43:9196-9201

Liu G, Zheng M, Cai M, Nie Z, Zhang B, Liu W, Du B, Dong S, Hu J, Xiao K (2013) Atmospheric emission of polychlorinated biphenyls from multiple industrial thermal processes. Chemosphere 90:24532460

Liu G, Lv P, Jiang X, Nie Z, Zheng M (2014) Identifying iron foundries as a new source of unintentional polychlorinated naphthalenes and characterizing their emission profiles. Environ Sci Technol 48: 13165-13172

Luthardt P, Mayer J, Fuchs J (2002) Total TEQ emissions (PCDD/F and PCB) from industrial sources. Chemosphere 46:1303-1308

Lv P, Zheng M, Liu G, Liu W, Xiao K (2011) Estimation and characterization of $\mathrm{PCDD} / \mathrm{Fs}$ and dioxin-like $\mathrm{PCBs}$ from Chinese iron foundries. Chemosphere 82:759-763

Meijer S, Ockenden W, Sweetman A, Breivik K, Grimalt J, Jones K (2003) Global distribution and budget of PCBs and HCB in background surface soils: implications for sources and environmental processes. Environ Sci Technol 37:667-672

Nie Z, Liu G, Liu W, Zhang B, Zheng M (2012) Characterization and quantification of unintentional POP emissions from primary and secondary copper metallurgical processes in China. Atmos Environ 57:109-115

Ren N, Que M, Li Y, Liu Y, Wan X, Xu D, Sverko E, Ma J (2007) Polychlorinated biphenyls in Chinese surface soils. Environ Sci Technol 41:3871-3876 
Tian B, Huang J, Wang B, Deng S, Yu G (2012) Emission characterization of unintentionally produced persistent organic pollutants from iron ore sintering process in China. Chemosphere 89:409-415
Van BM, Birnbaum LS, Denison M, De VM, Farland W, Feeley M, Fiedler H, Hakansson H, Hanberg A, Haws L (2006) The 2005 World Health Organization reevaluation of human and mammalian toxic equivalency factors for dioxins and dioxin-like compounds. Toxicol Sci 93:223-241 